\title{
Assessment of the haematological parameters and biochemical indices of albino rats fed with spores of Trichoderma viride
}

\section{Esther Aanuoluwa Ekundayo}

Department of Biological Sciences, University of Medical Sciences, Ondo Nigeria. Email: eekundayo@unimed.edu.ng.

\begin{abstract}
The haematological as well as some enzymes biomarkers of albino rats orogastically dosed with different concentrations of Trichoderma viride as well as T. viride subjected to various treatments were evaluated. Generally, red blood cell count, haemoglobin content and packed cell volume of the control group were significantly higher than that of animals dosed with different concentrations of $T$. viride. The same trend was observed when $T$. viride was amended with $1 \%$ lactose, sodium nitrate and sodium chloride. There were no significant differences in the alanine aspartate, alkaline phosphatase and alanine transaminase values of animals dosed with lower concentrations of $T$. viride. This study suggests that lower concentration of $T$. viride could be used in controlling fungal phytopathogens.
\end{abstract}

Keywords: Trichoderma viride; Enzyme biomarkers; Albino rats; Heamatology; Orogastically dosed.
Received

April 24, 2020

Accepted

November 30, 2020

Released

December 31, 2020

Full Text Article

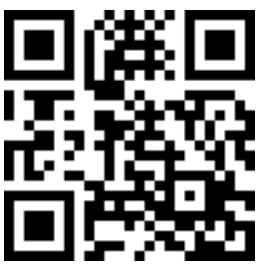

ORCID

(1) 0000-0003-1493-2530

Esther Aanuoluwa

Ekundayo

\section{Introduction}

Phytopathogenic fungi are known cause a lot of diseases to economically important crops worldwide (Gohel et al., 2006; Heydari and Pessarakli, 2010; Todorova and Kozhuharova, 2010). These diseases have been controlled by the application of large quantities of chemical fungicides. However, their extensive use causes serious pollution problem in the environment (Raghunathan and Divakar, 1996). Therefore, there is the need for an alternative (Zegeye et al., 2011).

According to Daayf et al. (2003)

Biological control using microorganisms to control these diseases provides protection essentially through production of antibiotics or other molecules that are deleterious to the pathogen's development, competition with the 
pathogen for nutrients and space or induced plant resistance (Daayf et al., 2003).

It employs natural enemies of pests or pathogens to eradicate or control their population. The induction of plant resistance using non-pathogenic or incompatible microorganisms is also a form of biological control (Cook, 1993; Schouten et al., 2004).

A host of plant pathogenic fungi such as Rhizoctonia solani, Pythium aphanidermatium, Fusarium oxysporum, Fusarium culmorum, Gaeumannomyces graminis var. tritici, Sclerotium rolfsii, Phytophthora cactorum, Botrytis cinerea and Alternaria spp. have been effectively controlled by Trichoderma species (Jones and Stewart, 1997; Kucuk and Kivanc, 2003; Dolatabadi et al., 2011).

Trichoderma spp. are free-living fungi that are common in as well as on plant surfaces (Islam et al., 2011). Trichoderma species lytic enzymes such as chitinases, glucanases and proteases which are essential in biocontrol of plant diseases (Gajera and Vakharia, 2012). Previous study by Ekundayo et al. (2015) has shown the antagonistic activities of $T$. viride against Sclerotium rolfsii, soil borne pathogen of many agricultural and horticultural crops. However, there is dearth of information on the toxicological effects of this particular fungus. Therefore, this present investigation was conducted to determine the effects of this fungus on the haematology and some enzymes biomarkers of albino rats.

\section{Materials and methods}

\section{Fungal isolates and treatment conditions}

Trichoderma viride, an isolate of maize cob was obtained from the Department of Microbiology, The Federal University of Technology, Akure (FUTA). The fungus was cultivated using LAB M potato dextrose broth in conical flask while other flasks containing T. viride was amended separately with $1 \% \mathrm{NaNO}_{3}$, lactose and $\mathrm{NaCl}$.

\section{Experimental animals}

A total number of 30 albino rats were obtained from the Department of Animal Production, The Federal University of Technology, Akure, and were caged in a well ventilated conditions. Prior to the experiments, the animals were weighed and stabilized for a period of 8 days by giving them grower mash prepared by Guinea Feed Nigeria Limited and water ad libitum.

\section{Animal grouping and administration of $T$. viride}

The animals were grouped into ten with three rats in a group for a period of 7 days. The treated albino rats were orogastically dosed with the different treatments: $1,0.5$, $0.1 \mathrm{~mL}$ T. viride, $1 \mathrm{~mL}$ T. viride supplemented with $1 \% \mathrm{NaNO}_{3}, 1 \mathrm{~mL}$ T. viride supplemented with $1 \% \mathrm{NaCl}$, and $1 \mathrm{~mL} \mathrm{~T}$. viride supplemented with $1 \%$ lactose. There were 4 sets of control, (1) animals fed with $1 \mathrm{~mL} \mathrm{NaNO}$, (2) those fed with $1 \mathrm{~mL}$ lactose, (3) those fed with $1 \mathrm{~mL} \mathrm{NaCl}$, and (4) those fed with clean water only. After the expiration of 7 days of treatment, the animals were sacrificed and their haematological parameters and enzyme biomarkers were determined (Adebolu et al., 2011).

\section{Haematological analysis of blood samples}

The blood samples were collected into EDTA anticoagulant bottles. Haematological parameters; packed cell volume (PCV), haemoglobin (Hb), white blood cell (WBC), mean cell haemoglobin concentration (MCHC) and differential leucocyte count for lymphocytes, neutrophil, eosinophil, basophil, and monocytes were determined according to standard methods (D'Armour et al., 1956; Wintrobe et al., 1961; Aning et al., 1998). 


\section{Determination of liver functioning tests}

Some liver functioning tests, aspartate aminotransferase (AST), alanine aminotransferase (ALT) and alkaline phosphatase (ALP) were determined according to the protocols of Babson et al. (1966) and Momoh et al. (2013).

\section{Data analysis of results}

The data collected were then subjected to Analysis of variance (ANOVA) and the means were separated by Duncan's New Range Multiple Test at $\mathrm{P}=0.05$, using SPSS version 15.0 Microsoft Windows XP.

\section{Results}

Table 1 shows the haematological parameters of albino rats subjected to various treatments. The results show a significant difference in the erythrocyte sedimentation rate of all the treatments. The highest erythrocyte value was obtained from $\mathrm{NaNO}_{3}+T$. viride. There was no significant difference in the packed cell volume of albino rats fed with basal diet and lactose. The least PCV was obtained from rats fed with $\mathrm{NaNO}_{3}+T$. viride. Also, the highest haemoglobin content was obtained from control group although there was no significant difference in the haemoglobin content of lactose and $\mathrm{NaCl}$ fed albino rats. The white blood cell count of albino rats fed with $1.0 \mathrm{~mL}$ of $T$. viride was significantly higher than that of control group.

Table 1. Haematological parameters of albino rats under various treatments.

\begin{tabular}{|l|c|c|c|c|c|}
\hline Treatment & ESR (\%) & PCV (\%) & HB (\%) & $\begin{array}{c}\text { WBC } \\
(\times \mathbf{1 0}) / \mathbf{m m}^{\mathbf{3}}\end{array}$ & RBC (\%) \\
\hline T. viride $1 \mathrm{~mL}$ & $8.00 \pm 1.32 \mathrm{a}$ & $27.00 \pm 1.00 \mathrm{~d}$ & $9.00 \pm 0.33 \mathrm{e}$ & $17.57 \pm 1.60 \mathrm{a}$ & $6.47 \pm 0.45 \mathrm{de}$ \\
\hline T. viride $0.5 \mathrm{~mL}$ & $4.67 \pm 0.58 \mathrm{~b}$ & $29.67 \pm 0.58 \mathrm{c}$ & $9.89 \pm 0.19 \mathrm{~d}$ & $14.27 \pm 0.25 \mathrm{~b}$ & $8.00 \pm 0.87 \mathrm{bc}$ \\
\hline T. viride $0.1 \mathrm{~mL}$ & $2.50 \pm 0.50 \mathrm{de}$ & $34.00 \pm 1.00 \mathrm{~b}$ & $11.38 \pm 0.40 \mathrm{~b}$ & $10.13 \pm 0.68 \mathrm{~d}$ & $8.90 \pm 0.36 \mathrm{~b}$ \\
\hline $\mathrm{NaNo}_{3}(1 \mathrm{~mL})$ & $4.33 \pm 0.76 \mathrm{bc}$ & $30.00 \pm 1.00 \mathrm{c}$ & $9.99 \pm 0.36 \mathrm{~d}$ & $11.23 \pm 0.45 \mathrm{~cd}$ & $8.80 \pm 0.44 \mathrm{~b}$ \\
\hline $\mathrm{NaNo}_{3}+$ T. viride $(1 \mathrm{~mL})$ & $8.33 \pm 0.29 \mathrm{a}$ & $25.33 \pm 0.58 \mathrm{~d}$ & $8.39 \pm 0.25 \mathrm{e}$ & $15.90 \pm 1.40 \mathrm{~b}$ & $5.87 \pm 0.65 \mathrm{e}$ \\
\hline lactose $(1 \mathrm{~mL})$ & $1.00 \pm 0.00 \mathrm{f}$ & $38.00 \pm 1.00 \mathrm{a}$ & $12.81 \pm 0.20 \mathrm{a}$ & $11.67 \pm 0.35 \mathrm{~cd}$ & $9.10 \pm 1.05 \mathrm{~b}$ \\
\hline Lactose + T. viride & $3.33 \pm 1.04 \mathrm{~cd}$ & $31.67 \pm 1.53 \mathrm{c}$ & $10.57 \pm 0.55 \mathrm{~cd}$ & $14.80 \pm 1.47 \mathrm{~b}$ & $7.17 \pm 0.29 \mathrm{~cd}$ \\
\hline NaCl $(1 \mathrm{~mL})$ & $1.33 \pm 0.58 \mathrm{ef}$ & $37.00 \pm 1.73 \mathrm{a}$ & $12.22 \pm 0.56 \mathrm{a}$ & $12.23 \pm 0.60 \mathrm{c}$ & $8.53 \pm 0.35 \mathrm{~b}$ \\
\hline NaCl + T. viride $(1 \mathrm{~mL})$ & $2.33 \pm 0.58 \mathrm{de}$ & $31.00 \pm 1.00 \mathrm{c}$ & $10.76 \pm 0.52 \mathrm{bc}$ & $18.13 \pm 0.81 \mathrm{a}$ & $7.40 \pm 0.46 \mathrm{~cd}$ \\
\hline Control & $1.00 \pm 0.00 \mathrm{f}$ & $38.33 \pm 1.53 \mathrm{a}$ & $12.75 \pm 0.49 \mathrm{a}$ & $10.33 \pm 0.42 \mathrm{~d}$ & $10.30 \pm 0.82 \mathrm{a}$ \\
\hline
\end{tabular}

Note: Values are means of 3 replicates with standard deviation. Values followed by similar alphabets along each column are not significantly different from each other at P $\leq 0.05$. Keys - ESR: Erythrocyte sedimentation rate; PCV: Packed cell volume; Hb: Haemoglobin; WBC: White blood cell; RBC: Red blood cell.

The white blood cell differential count of albino rats treated with different concentrations of $T$. viride and T. viride supplemented diets presented in Table 2 . Lymphocytes of control and albino rats fed with $0.1 \mathrm{~mL}$ of $T$. viride were significantly higher than other treatments. Also, there were significant differences in the monocytes, neutrophils, eosinophis and basophils of the different treatments. 
Table 2. White blood cells differential counts of albino rats under various treatments.

\begin{tabular}{|l|c|c|c|c|c|}
\hline Treatment & LYM (\%) & MON (\%) & NEU (\%) & EOS (\%) & BAS (\%) \\
\hline T. viride $1 \mathrm{~mL}$ & $61.33 \pm 1.53 \mathrm{c}$ & $7.67 \pm 1.16 \mathrm{~b}$ & $28.00 \pm 1.00 \mathrm{bc}$ & $2.00 \pm 0.00 \mathrm{a}$ & $1.00 \pm 0.00 \mathrm{c}$ \\
\hline T. viride $0.5 \mathrm{~mL}$ & $65.33 \pm .53 \mathrm{~b}$ & $4.33 \pm 2.08 \mathrm{c}$ & $27.67 \pm 1.53 \mathrm{bc}$ & $1.67 \pm 0.58 \mathrm{~b}$ & $1.00 \pm 0.00 \mathrm{c}$ \\
\hline T. viride $0.1 \mathrm{~mL}$ & $69.67 \pm 0.58 \mathrm{a}$ & $7.67 \pm 0.58 \mathrm{~b}$ & $21.00 \pm 1.00 \mathrm{e}$ & $1.33 \pm 0.58 \mathrm{bc}$ & $0.33 \pm 0.58 \mathrm{c}$ \\
\hline $\mathrm{NaNo}_{3}(1 \mathrm{~mL})$ & $65.00 \pm 3.60 \mathrm{~b}$ & $4.33 \pm 2.08 \mathrm{c}$ & $25.67 \pm 2.08 \mathrm{~cd}$ & $1.33 \pm 0.58 \mathrm{bc}$ & $3.33 \pm 0.58 \mathrm{a}$ \\
\hline $\mathrm{NaNo}_{3}+$ T. viride $(1 \mathrm{~mL})$ & $62.67 \pm 1.16 \mathrm{bc}$ & $7.00 \pm 1.00 \mathrm{~b}$ & $26.33 \pm 1.53 \mathrm{~cd}$ & $2.00 \pm 0.00 \mathrm{a}$ & $2.00 \pm 0.00 \mathrm{~b}$ \\
\hline lactose $(1 \mathrm{~mL})$ & $61.67 \pm 1.53 \mathrm{c}$ & $9.00 \pm 1.00 \mathrm{a}$ & $28.00 \pm 1.00 \mathrm{bc}$ & $1.00 \pm 0.00 \mathrm{c}$ & $0.33 \pm 0.00 \mathrm{c}$ \\
\hline Lactose + T. viride & $65.67 \pm 1.16 \mathrm{~b}$ & $7.00 \pm 1.00 \mathrm{~b}$ & $24.33 \pm 2.08 \mathrm{~d}$ & $2.00 \pm 0.00 \mathrm{a}$ & $1.00 \pm 0.00 \mathrm{c}$ \\
\hline NaCl $(1 \mathrm{~mL})$ & $60.33 \pm 0.58 \mathrm{c}$ & $7.33 \pm 0.58 \mathrm{~b}$ & $29.33 \pm 0.58 \mathrm{~b}$ & $2.00 \pm 0.00 \mathrm{a}$ & $1.00 \pm 0.00 \mathrm{c}$ \\
\hline NaCl + T. viride $(1 \mathrm{~mL})$ & $56.67 \pm 1.16 \mathrm{~d}$ & $7.00 \pm 1.00 \mathrm{~b}$ & $33.33 \pm 1.53 \mathrm{a}$ & $2.00 \pm 0.00 \mathrm{a}$ & $1.00 \pm 0.00 \mathrm{c}$ \\
\hline Control & $70.33 \pm 1.53 \mathrm{a}$ & $7.00 \pm 1.00 \mathrm{~b}$ & $20.33 \pm 0.58 \mathrm{e}$ & $2.00 \pm 0.00 \mathrm{a}$ & $0.33 \pm 0.58 \mathrm{c}$ \\
\hline
\end{tabular}

Note: Values are means of 3 replicates with standard deviation. Values followed by similar alphabets along each column are not significantly different from each other at $\mathrm{P} \leq 0.05$. Keys - Lym: Lymphocyte; Mon: Monocyte; Neu: Neutrophil; Eos: Eosinophil; Bas: Basophil.

\section{Biochemical indices of albino rats treated with $T$. viride}

The AST values of animals fed with different concentrations of T. viride and T. viride supplemented with sodium chloride were significantly lower than the control. However, there was no significant difference in T. viride supplemented with lactose and sodium nitrate as well as the control (Figure 1). The ALP and ALT of T. viride supplemented with lactose, sodium chloride and sodium nitrate were higher than the control (Figures 2 and 3).

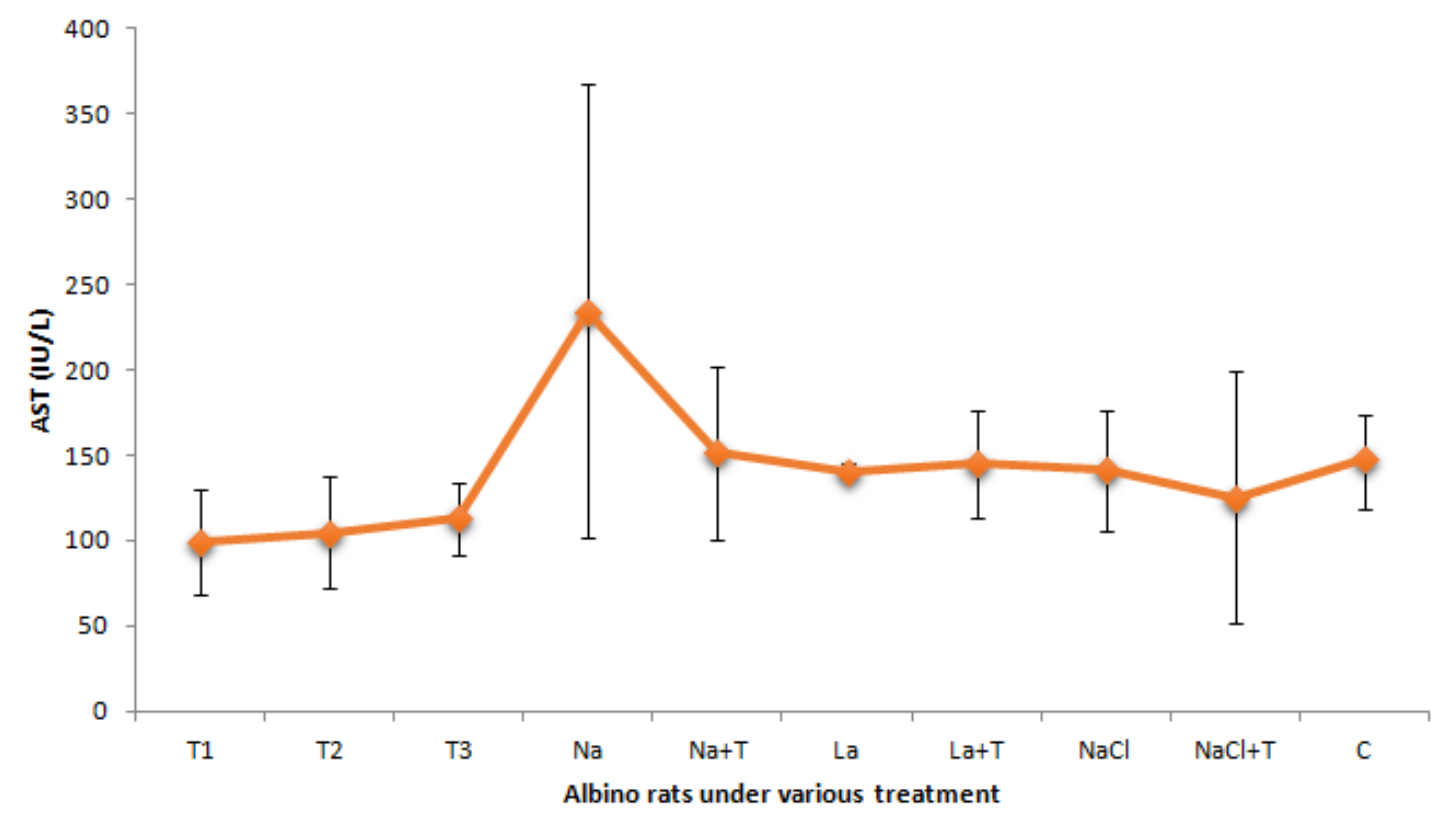

Figure 1. Alanine aspartate (AST) of albino rats under various treatments of Trichoderma viride. Keys - T1: $1.00 \mathrm{~mL}$ of T. viride; T2: $0.50 \mathrm{~mL}$ of T. viride; T3: $0.10 \mathrm{~mL}$ of T. viride; Na: Sodium nitrate $\left(\mathrm{NaNO}_{3}\right) ; \mathrm{Na}+\mathrm{T}$ : Sodium nitrate $\left(\mathrm{NaNO}_{3}\right)+$ T. viride; La: Lactose; La+T: Lactose + T. viride; NaCl: Sodium chloride; $\mathrm{NaCl}+\mathrm{T}$ : Sodium chloride + T. viride; $\mathrm{C}$ : Control. 


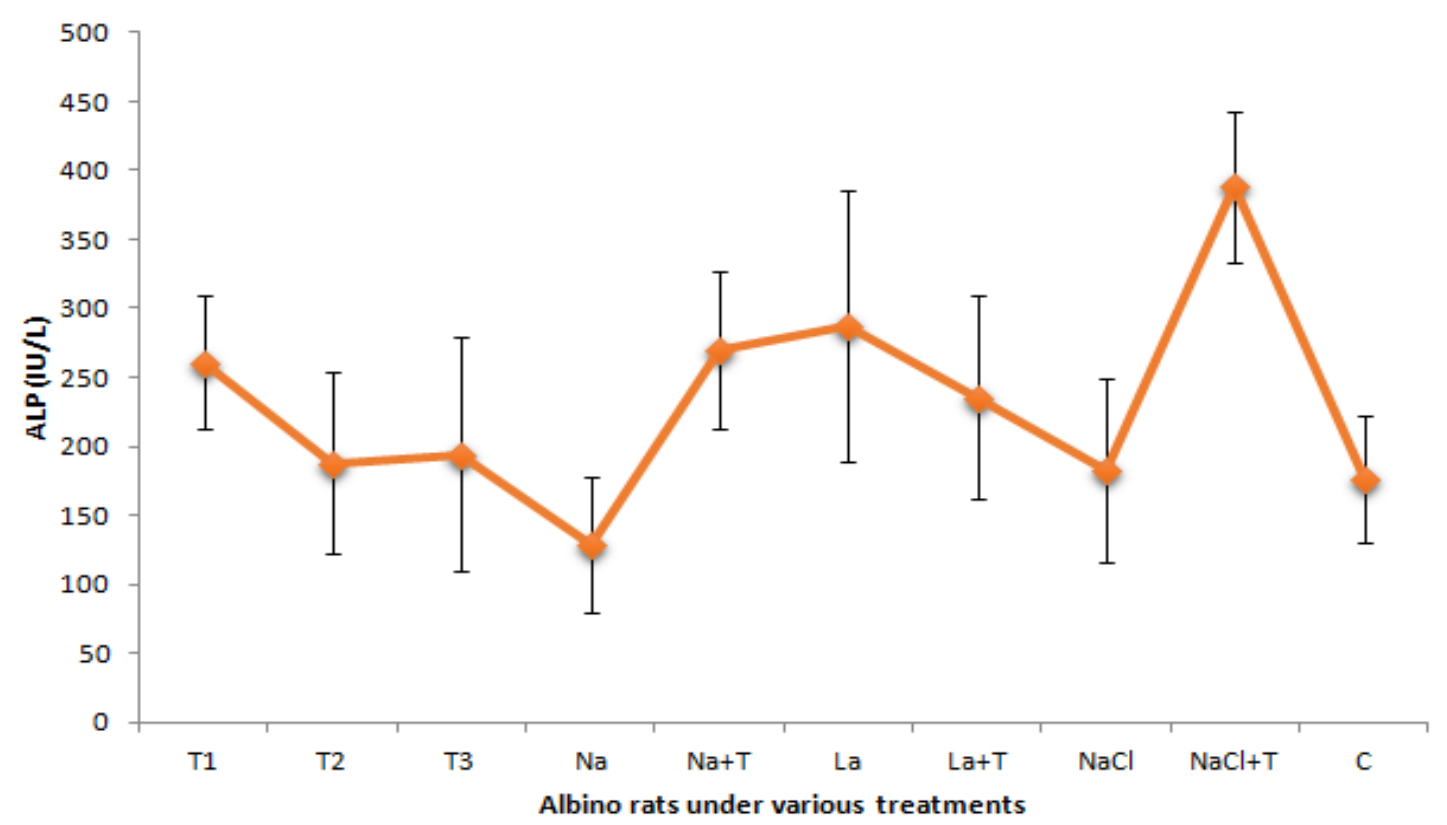

Figure 2. Alkaline phosphatase of albino rats under various treatments. Keys - T1: $1.00 \mathrm{~mL}$ of T. viride; T2: $0.50 \mathrm{~mL}$ of T. viride; T3: $0.10 \mathrm{~mL}$ of T. viride; Na: Sodium nitrate $\left(\mathrm{NaNO}_{3}\right) ; \mathrm{Na}+\mathrm{T}$ : Sodium nitrate $\left(\mathrm{NaNO}_{3}\right)+$ T. viride; La: Lactose; $\mathrm{La}+\mathrm{T}$ : Lactose + T. viride; NaCl: Sodium chloride; $\mathrm{NaCl}+\mathrm{T}$ : Sodium chloride + T. viride; $\mathrm{C}$ : Control.

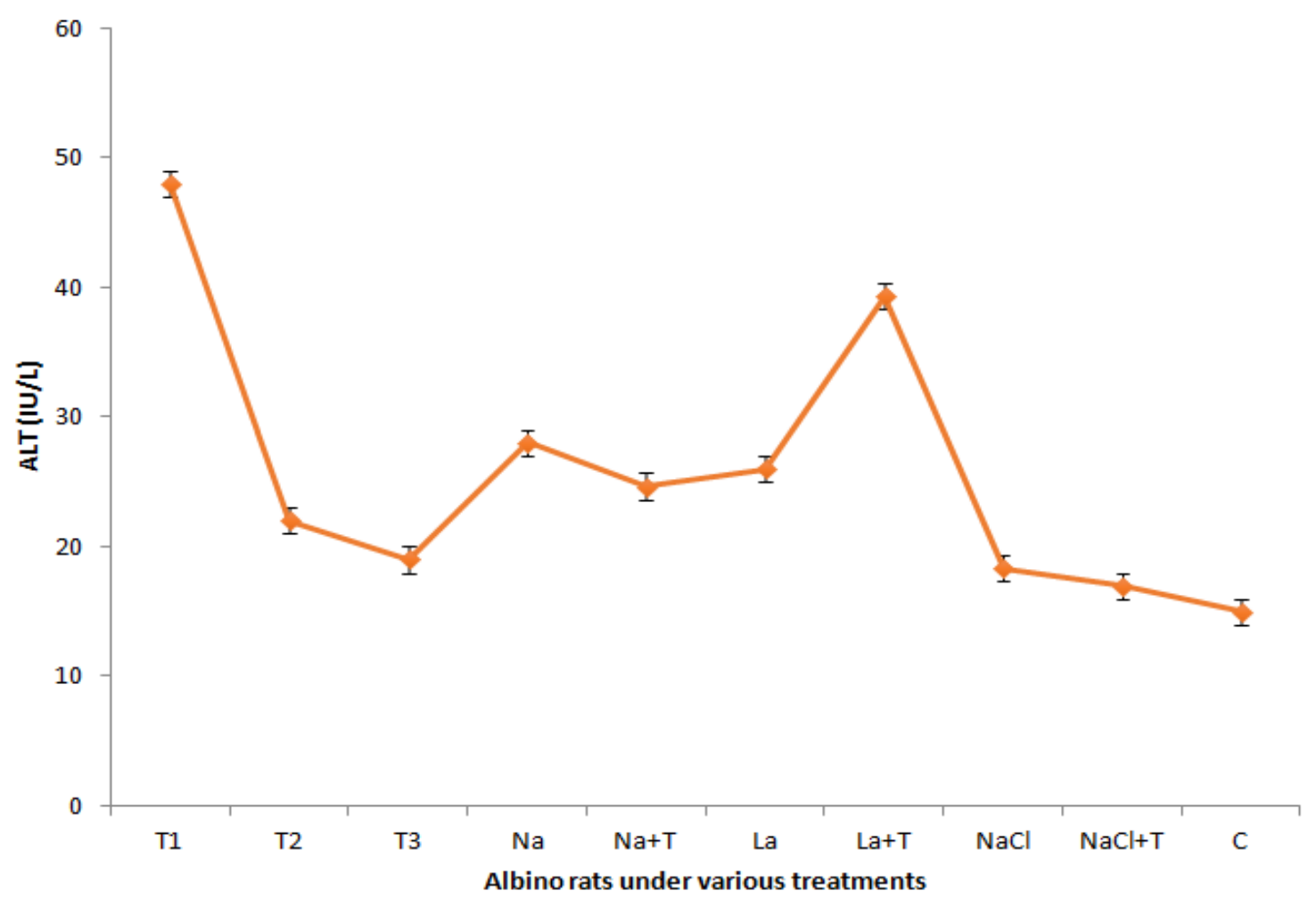

Figure 3. Alanine transaminase of albino rats under various treatments. Keys - T1: $1.00 \mathrm{~mL}$ of T. viride; T2: $0.50 \mathrm{~mL}$ of T. viride; T3: $0.10 \mathrm{~mL}$ of T. viride; Na: Sodium nitrate $\left(\mathrm{NaNO}_{3}\right) ; \mathrm{Na}+\mathrm{T}$ : Sodium nitrate $\left(\mathrm{NaNO}_{3}\right)+$ T. viride; La: Lactose; La+T: Lactose + T. viride; NaCl: Sodium chloride; $\mathrm{NaCl}+\mathrm{T}$ : Sodium chloride + T. viride; $\mathrm{C}$ : Control. 


\section{Discussion}

Haematological parameters are often used to determine the negative effects of a foreign substances on the blood. There was significant increase in the red blood cell (RBC), haemoglobin concentration $(\mathrm{Hb})$ and packed cell volume values of the untreated rats (control group) similar to the findings of Fasanu and Oyedapo (2008) and Ogunmefun et al. (2013). The decrease in RBC of treated group suggests that $T$. viride does not relatively possess haematinic property but causes anaemia. It can also be an indication that $T$. viride impaired the production of blood cells or the rate of destruction of matured red cells was greater than the rate of its production (Odeyemi et al., 2008).

Neutrophils which are matured cells usually attack and destroy bacteria in the blood (Dacie and Lewis, 1995). The significant increase in the neutrophils implied enhancement in the ability of the blood component to phagocytose. "Lymphocytes are the main effector cells of the immune system" (McKnight et al., 1999). Lymphocyte values were lowered in the treated groups showing that the immunological status of the body was not enhanced.

The biochemical indices are useful parameters in assessing the functionality of the liver and kidney (Odeyemi et al., 2008). The ALP is a marker enzyme of damage for plasma membrane and endoplasmic reticulum (Wright and Plummer, 1974; Shahjahan et al., 2004). Enzymes from diseased of damaged tissues may become recognizable in the serum presumably by leakage through altered cell membrane of the rat organs (Akanji and Ngaha, 1989). Supplementation of T. viride with sodium chloride, lactose and sodium nitrate caused a significant increase in the ALT and ALP indicating liver damage. The increase in ALT and ALP of rats fed with $1.00 \mathrm{~mL}$ of T. viride was an indication of the damage inflicted on the plasma membrane. "This increase may be due to distruption of the ordered lipid-bilayer of the membrane structure of the affected organ "(Yakubu et al., 2003). Decrease in alanine aspartate (AST) values of the different concentrations of $T$. viride proved there was no damage to the organs.

\section{Conclusion}

This research has shown that $T$. viride had dose and parameter specific effects on the haematological and biochemical parameters investigated. I equally acknowledge all authors whose works have been cited in the course of preparation of this manuscript.

\section{Acknowledgement}

The author is grateful to Dr. A. O, Momoh of the Department of Biological Sciences, Elizade University for his assistance in the haematological studies.

\section{Conflict of interest}

Author declares that there are no conflict of interest.

\section{References}

Adebolu, T. T.; Adeoye, O. O.; Oyetayo, V. O. Effect of garlic (Allium sativum) on Salmonella typhi infection, gastrointestinal flora and haematological parameters of albino rats. African Journal of Biotechnology, v. 10, no. 35, p. 6804-6808, 2011. 
Akanji, M. A.; Ngaha, E. O. Effect of repeated administration of berenil on urinary excretion with corresponding tissue pattern in rats. Pharmacology \& Toxicology, v. 64, p. 272-275, 1989. https://doi.org/10.1111/j.1600-0773.1989.tb00645.x

Aning, K. G.; Ologun, A. G.; Onifade, A.; Alokan, J. A.; Aletor, V. A. Effect of replacing dried brewer's grains with 'sorghum rootlets' on growth, nutrient utilization and some blood constituents in the rat. Animal Feed Science and Technology, v. 71, p. 185-190, 1998. https://doi.org/10.1016/S0377-8401(97)00127-2

Cheesebrough, M. Medical laboratory manual for tropical countries: Anatomy and physiology, clinical chemistry and parasitology. 2. ed. London: Butterworth-Heinemann, 1991. v. 1.

Cook, R. J.; Baker, K. F. The nature and practice of biological control of plant pathogens. St. Paul: American Phytopathological Society, 1983.

D'Armour, F. E.; Blood, F. R.; Belden, D. A. The manual for laboratory work in mammalian physiology. 3. ed. Illinois, Chicago: The University of Chicago Press, 1956.

Daayf, F.; Adam, L.; Fernando, W. G. D. Comparative screening of bacteria for biological control of potato late blight (strain US-8) using in vitro, detached leaves and whole planting testing systems. Canadian Journal of Plant Pathology, v. 25, p. 276-284, 2003. https://doi.org/10.1080/07060660309507080

Dacie, F. V.; Lewis, S. M. Practical haematology. 7. ed. Edinburg: Churchill Livingstone, 1995.

Dolatabadi, K. H.; Goltapeh, E. M.; Varma, A.; Rohani, N. In vitro evaluation of arbuscular mycorrhizal-like fungi and Trichoderma species against soil borne pathogen. Journal of Agricultural Technology, v. 7, no. 1, p. 73-84, 2011.

Ekundayo, E. A.; Ekundayo, F. O.; Osinowo, I. A. Antifungal activities of Trichoderma viride and two fungicides in controlling diseases caused by Sclerotium rolfsii on tomato plants. Advances in Applied Science Research, v. 6, no. 3, p. 12-19, 2015.

Fasanu, P. 0.; Oyedapo, O. O. Phytopharmacology and therapeutic values. Recent Progress in Medicinal Plants, v. 19, no. 1, p. 39-47, 2008.

Gajera, H. P.; Vakharia, D. N. Production of lytic enzymes by Trichoderma isolates during in vitro antagonism with Aspergillus niger, the causal agent of collar rot of peanut. Brazilian Journal of Microbiology, v. 43, no. 1, p. 43-52, 2012. https://doi.org/10.1590/S151783822012000100005

Gohel, V.; Singh, A.; Vimal, M.; Ashwini, P.; Chhatpar, H. S. Bioprospecting and antifungal potential of chitinolytic microorganisms. African Journal Biotechnology, v. 5, p. 54-72, 2006.

Heydari, A.; Pessarakli, M. A review on biological control of fungal plant pathogens using microbial antagonists. Journal of Biological Sciences, v. 10, p. 273-290, 2010. https://doi.org/10.3923/jbs.2010.273.290

Islam, M. S.; Ali, M.; Rahman, M. S. In vitro studies on the fungicidal effect on Trichoderma species in tea plantation. Bangladesh Journal of Agricultural Research, v. 36, no. 4, p 677-683, 2011. https://doi.org/10.3329/bjar.v36i4.11758

Jones, E. E.; Stewart, A. Biological control of Sclerotinia minor in lettuce using Trichoderma species. Proceedings of New Zealand Plant Protection Conference, v. 50, p. 154-158, 1997. 
Kucuk, C.; Kivanc, M. Isolation of Trichoderma spp. and determination of their antifungal, biochemical and physiological features. Turkish Journal of Biology, v. 27, p. 247-253, 2003.

McKnight, D. C.; Mills, R. G.; Bray, J. J.; Crag, P. A. Human physiology. 4. ed. Edinburg: Churchill Livingstone, 1999.

Momoh, A. O.; Adebolu, T. T.; Ogundare A. O. Evaluation of beniseed extract and fermented liquor in treatment of diarrhoea in albino rats infected with Salmonella typhi. European Journal of Biology and Medical Science Research, v. 1, no. 2, p. 16-23, 2013.

Odeyemi, O. O.; Yakubu, M. T.; Masika, P. J.; Afolayan, A. J. Effect of administration of the essential oil from Tagetes minuta L. leaves in Wistar rats. Journal of Biological Sciences, v. 8, no. 6, p. 1067-1071, 2008. https://doi.org/10.3923/jbs.2008.1067.1071

Ogunmefun, O. T.; Fasola, G. R.; Saba, A. B.; Oridupa, O. A. The toxicity evaluation of Phragmanthera incana (Klotzsch) growing on two plant hosts and its effect on Wistar rats' haematology and serum biochemistry. Academic Journal of Plant Science, v. 6, no. 2, p. 92-98, 2013.

Raghunathan, V.; Divakar, B. J. Integrated pest management strategies. In: Gunasekaran, M.; Weber, D. J. (Eds.). Molecular biology of the biological control of pests and disease of plants. Florida: CRC Press, 1996. p. 191-194.

Schouten, A.; Van Den Berg, G.; Edel-Hermann, V.; Steinberg, C.; Gautheron, N.; Alabouvette, C.; Vos, C. H.; Lemanceau, P.; Raaijmakers, J. M. Defense responses of Fusarium oxysporum to 2,4-DAPG, a broad spectrum antibiotic produced by Pseudomonas fluorescens. Molecular Plant-Microbe Interactions, v. 17, p.1201-1211, 2004. https://doi.org/10.1094/mpmi.2004.17.11.1201

Shahjahan, M.; Sabitha, K. E.; Jamu, M.; Shyamala-Dev, C. S. Effect of Solanum trilobatum against carbon tetrachloride induced hepatic damage in albino rats. Indian Journal of Medical Research, p. 120, v. 194-198, 2004.

Todorova, S.; Kozhuharova, L. Characteristics and antimicrobial activity of Bacillus subtilis strains isolated from soil. World Journal of Microbiology and Biotechnology, v. 26, p. 1207-1216, 2010. https://doi.org/10.1007/s11274-009-0290-1

Wintrobe, M. M.; Lee, G. R.; Boggs, D. R.; Bithel, T. C.; Athens, J. W.; Foerester, J. Clinical haematology. 5. ed. Philadelphia: Les and Febiger, 1961.

Wright, P. J.; Plummer, D. T. The use of urinary enzyme measurement to detect renal damage caused by nephrotoxic compounds. Biochemical Pharmacology, v. 23, p. 65-73, 1974. https://doi.org/10.1016/0006-2952(74)90314-1

Yakubu, M. T.; Bilbis, L. S.; Lawal, M.; Akanji, M. A. Evaluation of selected parameters of rat liver and kidney function following repeated administration of yohimbine. Biokemistri, v. 15, no. 2, p. 50-56, 2003.

Zegeye, W. D.; Santhanam, A.; Gorfu, D.; Tessera, M.; Kassa, B. Biocontrol activity of Trichoderma viride and Pseudomonas fluorescens against Phytophthora infestans under greenhouse conditions. Journal of Agricultural Technology, v. 7, no. 6, p. 1589-1602, 2011.

License information: This is an open-access article distributed under the terms of the Creative Commons Attribution License, which permits unrestricted use, distribution, and reproduction in any medium, provided the original work is properly cited. 